Tanju Aslışen, E. H. ve Hakkoymaz, S. (2020). Erken okuryazarlık alanında gerçekleştirilmiş lisansüstü tez çalışmalarının incelenmesi: Bir içerik analizi. Ana Dili Eğitimi Dergisi, 8(4), 1483-1498.

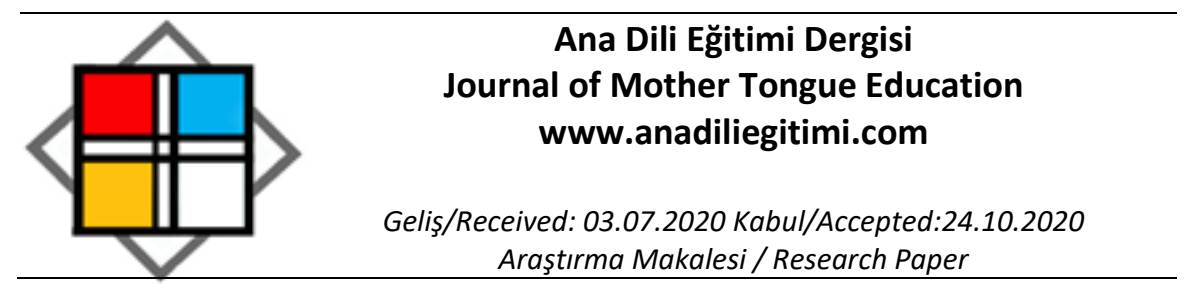

\title{
Erken Okuryazarlık Alanında Gerçekleştirilmiş Lisansüstü Tez Çalışmalarının İncelenmesi: Bir İçerik Analizi*
}

\author{
Ebru Hasibe TANJU ASLIŞEN** \\ Sakine HAKKOYMAZ ${ }^{* * *}$
}

\begin{abstract}
Öz
Bu çalışmanın amacı, yurt dışı ve yurt içinde 2015 ve 2020 yılları arasında erken okuryazarlık alanında gerçekleştirilmiş lisansüstü tezlerin incelenmesidir. Bu alandaki tez çalışmalarını belirlemek üzere ProQuest Dissertations and Theses ve Yüksek Öğretim Kurulu Ulusal Tez Merkezi veri tabanlarından 29.03.2020 ve 27.04.2020 tarihleri arasında tarama yapılmış, elde edilen veri seti bazı ölçütlere göre belirlenmiştir. Bu araştırmadaki ölçüt, tezlerin erken okuryazarlık alanında olması, eğitim-öğretim konu alanı kapsamında yer alması ProQuest Dissertations and Theses ve YÖK Ulusal Tez Merkezi'nde kayıtlı, erişim izinlerinin olmasıdır. Bu ölçütleri karşılayan toplam 73 lisansüstü tez çalışmaya dâhil edilmiştir. Araştırma, nitel bir araştırma olup veriler doküman incelemesi tekniğiyle toplanmıştır. Tezler hakkındaki detaylı bilgiler, araştırmacılar tarafından geliştirilen "Lisansüstü Tez İnceleme Formu" aracılığıyla toplanmıştır. Verilerin çözümlenmesinde frekans (f) ve yüzdelerden (\%) yararlanılmıştır. Tez çalışmalarının tez türüne göre dağılımları incelendiğinde yurt içinde en fazla yüksek lisans düzeyinde, yurt dışında ise doktora düzeyinde tez çalışmalarının gerçekleştirildiği tespit edilmiştir. Yurt içi lisansüstü tezlerde nicel araştırma desenlerinin daha ağırlıklı kullanıldığı görülürken, yurt dışında ise nitel araştırma desenlerinin tercih edildiği sonucuna ulaşılmıştır. Çalışma grubunda çocukların yer aldığı lisansüstü tezlerde çoğunlukla nicel araştırma deseni altında ölçme araçlarının kullanıldığı, bunların uyarlama çalışması önceden yapılmış hazır ölçekler olduğu ve bu şekilde araştırmalarda yer aldığı belirlenmiştir. Nitel araştırma deseninde yürütülen tezlerde ise görüşme ve gözlem yönteminin sıklıkla kullanıldı̆̆ı ve tüm araştırmalarda ortak olan tek veri toplama aracının, her araştırmanın amacına bağlı olarak geliştirilen kişisel bilgi formu olduğu gözlenmiştir. Araştırmanın bulguları doğrultusunda, erken okuryazarlığın ele alındığı çok boyutlu çalışmaların yürütülmesi önerilmektedir.
\end{abstract}

Anahtar Sözcükler: Erken okuryazarlık, okul öncesi dönem, erken çocukluk, alıcı ve ifade edici dil

\begin{abstract}
Analysis of Postgraduate Theses on Early Literacy: A Content Analysis
Abstract

The present study aims to analyze postgraduate theses on early literacy conducted in Turkey and abroad between 2015 and 2020. In order to select theses on this field, scanning was conducted between 29.03.2020 and 27.04.2020 on databases including ProQuest Dissertations and the Council of Higher Education's National Thesis Center. The criterion in this research is that the theses are in the field of early literacy, being in the field of education and training, being registered in ProQuest Dissertations and Theses and the Council of Higher Education's National Thesis Center, having access permissions. 73 postgraduate theses in total meeting these criteria were included in the study. The study is a qualitative one and data were collected by the document analysis
\end{abstract}

\footnotetext{
* Bu çalışma, 27-28-29 Haziran tarihleri arasında düzenlenen 5. Ulusal Disiplinlerarası Erken Çocuklukta Müdahale Kongresinde (UDEMKO 2020) sözlü bildiri olarak sunulmuştur.

** Doç. Dr., Ankara Hacı Bayram Veli Üniversitesi, Polatlı Sosyal Bilimler Meslek Yüksekokulu, Çocuk Bakımı ve Gençlik Hizmetleri Bölümü, Ankara. ebru.aslisen@hbv.edu.tr, ORCiD: 0000-0003-3306-2438

*** Dr. Öğr. Üyesi., Hasan Kalyoncu Üniversitesi, Eğitim Fakültesi, Temel Eğitim Bölümü, Sınıf Eğitimi Anabilim Dalı, Gaziantep, sakine.hakkoymaz@hku.edu.tr, ORCiD: 0000-0002-3005-7900
} 
technique. Detailed information on the theses was collected through the "Postgraduate Thesis Analysis Form" developed by the researchers. Frequency (f) and percentages (\%) were used in data analysis. When the researcher analyzed these theses according to their distribution by thesis type, it was observed that the majority was at master's level in Turkey whereas the majority was at doctoral level abroad. While it was seen that quantitative research designs were used more in postgraduate theses in Turkey, it was concluded that qualitative research designs were preferred abroad. Based on research findings, the research recommends that multidimensional studies focusing on early literacy be conducted.

Keywords: Early literacy, preschool period, early childhood, receptive and expressive language

\section{Giriş}

İnsan yaşamında erken çocukluk döneminin çok önemli bir yeri vardır. Bu dönem; çocukların tüm gelişim alanlarında hızlı ilerlemelerin kaydedildiği sihirli yıllar olarak kabul edilmekte, sosyalduygusal, bilişsel ve dil becerilerinin kazandırımasında kritik bir önem taşımaktadır. Gelişiminin bütüncül olduğu göz önüne alındığında okuma-yazma becerisinin kazandırıması için etkileyici ve belirleyici bir dönem özelliği taşıyan erken çocuklukta, karmaşık ve aktif bir süreç izlenmektedir. Erken okuryazarlık becerisi; alan yazında ilköğretim yıllarındaki okuma yazma öğretimi öncesinde çocukların sahip olmaları gereken bilgi, beceri ve tutumlar şeklinde tanımlanmakta (Evans, Bell, Shaw, Moretti \& Page, 2006; Gök 2013; Lerner 2000; Scarborough, 2018; Whitehurst \& Lonigan, 2001) ve okuma başarısının en güçlü belirleyicilerinden biri olarak kabul edilmektedir. Ayrıca bu araştırmalarda okuma yazma gelişimsel bir süreç olarak değerlendirilmiş, yaşamın ilk yıllarına dikkat çekilmiştir.

Erken okuryazarlığın bileşenlerini oluşturan; fonolojik farkındalık, görsel algı, yazı farkındalığı, harf bilgisi, alıcı ve ifade edici dil gibi becerilerin ilerleyen yıllarda da çocuğun okuma performansları için kuvvetli bir belirleyici olduğu birçok araştırmada vurgulanmıştır (Elliott \& Olliff, 2008; Kargın, Ergül, Büyüköztürk \& Güldenoğlu; 2015; Spira, Bracken \& Fischel, 2005). Görüldüğü gibi erken okuryazarlık, formal okuma yazmayı öğrenmeden önceki birçok ön becerinin kazanılmasında önkoşul durumundadır.

Whitehurst ve Lonigan (2001) yaptıkları çalışmada, erken okuryazarlık sürecinde çocuklara formal okuma yazmaya geçmeden önce sözcük bilgisi, kelime dağarcığı, fonolojik farkındalık, görsel algı, harf farkındalığı, yazı farkındalığı ile dinlediğini ve okuduğunu anlama gibi birtakım becerilerin sunulduğunu ifade etmişlerdir. Phillips ve Lonigan (2009) da benzer olarak erken okuryazarlık kavramını, bebeklik döneminde gelişme gösteren ve erken çocukluk dönemi boyunca keşifler ve eğitimsel fırsatlarla zenginleştirilen beceri seti ve bilgi tabanı şeklinde tanımlamışlardır. Bu tanımlardan hareketle erken okuryazarlığın çocuklarda erken yaşlardan itibaren özen gösterilerek geliştirilmesi ve takip edilmesi gereken bir süreç olduğunu söylemek mümkündür. Bu süreçte amaç, çocuklara okumayı ve yazmayı öğretmek değil, onlarda okuma için gerekli temeli oluşturmaktır (MacLean, 2008).

Günümüzde yapılan pek çok çalışma, erken okuryazarlık becerilerinin, çocuğun hayat boyu öğrenmesini destekleyen temel gereksinimlerden biri olduğunu, gelecekteki okuma yazma ve akademik becerilerini kuvvetli bir şekilde desteklediğini göstermiştir (Beaty, 2018; Dickinson \& Neuman, 2018; Kalburan, 2010). Ancak erken çocukluk yıllarında çevreyle yeterince etkileşime girmemiş ve ön okuryazarlık becerilerini yeterince kazanamamış çocukların, formal okuma ve yazma öğrenimine geçtiklerinde görsel algı (Ferah 2001), sözcük dağarcığı (Karaman, 2015), fonolojik farkındalık (Erdoğan, 2012), yazma becerisi (Bayraktar \& Temel, 2014) harf ve sözcük tanıma (Whitehurst \& Lonigan, 2001) ve okuma becerisi (McGee \& Morrow, 2005; National Early Literacy Panel [NELP], 2008) gibi birtakım güçlüklerle karşı karşıya kalabilecekleri yapılan araştırmalarla gözler önüne serilmiştir.

Okul öncesi dönemde ailelerin ve öğretmenlerin çocuklar için oluşturduğu oyun ortamları, kitap okuma ve resim yapma etkinlikleri gibi birçok etkileşimin var olduğu durumlar, çocukların okuma alışkanlığı edinmelerinde, okuduğunu anlamalarında, üretici dili etkili bir şekilde kullanmalarında ve kendilerini ifade edebilmelerinde kısacası erken okuryazarlık becerilerinin gelişmesinde son derece önemli deneyimler sağlamaktadır. Bu sayede çocuklarda fonolojik yapıdaki oyunları oynama ve sesleri fark edebilme, hecelerdeki uyakları kavrama, resimli kitapları eğlence aracı olarak görme gibi birçok davranış gözlenmekte (Whitehurst \& Lonigan, 2001; Zucker, Cabell, Justice, Pentimonti \& Kadevarek, 
2013), ilerleyen dönemlerdeki akademik becerileri de desteklenmektedir (Bredekamp, 2015; Justice \& Ezell, 2001; Karaman, 2015; Spira, Bracken \& Fischel, 2005). Dolayısıyla erken çocukluk döneminde gerçekleştirilen nitelikli öğrenme yaşantılarının öncelikli olarak erken okuryazarlık becerilerine, ileriki yıllarda da yüksek akademik başarıya katkısı yadsınamaz.

Son yıllarda yapılan çalışmalar ve ilgili alan yazın incelendiğinde erken okuryazarlık becerileri konusunda yapılan lisansüstü çalışmaların her geçen gün sayıca arttığı görülmüştür. Lisansüstü tezler, üniversitelerin araştırma yönünü desteklemekle birlikte alandaki gelişmeleri ortaya koyması açısından da son derece önemli bir işleve sahiptir. Bu çalışma erken okuryazarlık alanında son beş yılda ülkemizde ve yurt dışında yapılan lisansüstü tezlerinin araştırma eğilimlerinin belirlemesi amacıyla gerçekleştirilmiştir. Belli bir konu alanında o zamana kadar yapılmış araştırmaları analiz etmenin gelecekteki çalışmalara yol göstereceği düşüncesinden hareketle bu çalışmada; erken okuryazarlık alanında 2015- 2020 yılları arasında yapılmış lisansüstü tezlerin dağılımları; yayınlandıkları yıl, üniversite, hedef kitle, yöntem ve veri toplama araçları göz önüne alınarak incelenmiştir. Erken okuryazarlık alanında çalışmak isteyen araştırmacılara, okul öncesi öğretmenlerine ve ailelere bu alanda yapılmış çalışmaları sunarak durum tespitinde bulunabilmek ve özellikle yapılacak yeni çalışmalara ışık tutabilmek bu çalışmanın en önemli amaçlarından biridir.

\section{Araştırma Modeli}

\section{Yöntem}

Erken okuryazarlık alanıyla ilgili 2015-2020 yılları arasında ülkemizde ve yurt dışında yapılan lisansüstü tezlerin araştırma eğilimlerinin belirlenmesi amacıyla gerçekleştirilen çalışmanın verileri, nitel araştırma yöntemlerinden doküman incelenmesi kullanılarak toplanmıştır. Doküman incelemesi, araştırılması hedeflenen olgu ya da olaylar hakkında bilgi içeren yazılı materyallerin analizini kapsamaktadır (Yıldırım \& Şimşek, 2018). Doküman incelemesi gerçekleştirilirken verileri düzenleme, inceleme, kodlama, tema ve kategorilere ayırma, nasıl sunulacağını belirleme ve bulguları yorumlama olmak üzere izlenmesi gereken bazı aşamalar bulunmaktadır (Creswell, 2013).

\section{Araştırmanın Veri Seti}

Erken okuryazarlık alanında yapılan tez çalışmalarını belirlemek üzere ProQuest Dissertations and Theses ve Yükseköğretim Kurulu (YÖK) Ulusal Tez Merkezi veri tabanlarından tarama yapılmış ve araştırmanın veri seti birtakım ölçütlere göre belirlenmiştir. Bu araştırmadaki ölçüt, tezlerin erken okuryazarlık becerilerini içermesi, yalnız eğitim-öğretim konu alanı kapsamında yer alması, ProQuest Dissertations and Theses ile YÖK Ulusal Tez Merkezi'nde kayıtlı ve erişim izninin olmasıdır. Bu kapsamda, tarama yapılan tüm alanlarda ortak olarak ulaşılan ve belirlenen kriterlere uyan toplam 73 lisansüstü tez çalışması araştırmanın veri setini oluşturmaktadır.

\section{Verilerin Toplanması}

Doküman analizinin ilk aşamasında, veri setine dahil edilen lisansüstü tezlerin ProQuest Dissertations and Theses ve YÖK Ulusal Tez Merkezi veri tabanlarından tam metinlerine ulaşıımıştır. Kavram taraması yapılırken "early literacy, emergent literacy, erken okuryazarlık, gelişen okuryazarlık, okul öncesi okuryazarlık" anahtar kelimeleri kullanılmış ve başlangıçta toplam 80 lisansüstü tez çalışmasına ulaşılmış, bunlardan 73'ü çalışmaya dahil edilmiştir. Geri kalan 7 lisansüstü tez çalışması belirlenen ölçütlere uygun olmadığı için kapsam dışında bırakılmıştır. Çalışmanın verileri; ProQuest Dissertations and Theses ve YÖK Ulusal Tez Merkezi internet sitesi üzerinden araştırmanın başlangıç tarihi olan 29.03.2020'de toplanmaya başlanmış ve yeni herhangi bir lisansüstü tez çalışmasının eklenip eklenmediğinin kontrolü için 27.04.2020 tarihinde de tekrar tarama yapılarak kontrol sağlanmış ve karşılaştırmalar sonucunda her iki tarihte de aynı tez çalışmalarının yer aldığı tespit edilmiştir. 2020 yılı Nisan ayı sonuna kadar yapılan ve veri tabanlarında yer verilen çalışmalar bu araştırma kapsamına alınmış, çalışmanın amacına yönelik olarak lisansüstü tezlerin türleri, amaçları, çalışma grupları, yöntemleri, desenleri ve veri toplama araçları açısından gruplandırılması yapıımıştır. 


\section{Verilerin Analizi}

Çalışma verilerinin analizinde içerik analizinden faydalanılmıştır. İçerik analizi, genel olarak fazla sayıdaki metin içeriklerinin ortak yönlerini ortaya koymak için, önemli olan anlamların yapılandırılmasına ve sınıflandııımasına yönelik, nitelden nicele doğru genelleştirmeye imkân tanıyan bir analiz şeklidir (Gökçe, 2006, s. 17-18). Birbirine benzeyen verileri belirli kavramlar ve temalar çerçevesinde birleştirmeyi ve belirli bir düzen içerisinde yorumlamayı gerektiren (Yıldırım ve Şimşek, 2018) içerik analizi, daha önce gerçekleştirilmiş yazılı çalışmalar hakkında pek çok bilgi sunan çok değerli bilgi kaynağıdır. Çalışmanın ilk aşamasında incelenecek tezler, yıllar bazında türleri, amaçları, çalışma grupları, yöntemleri, desenleri ve veri toplama araçları bağlamında kodlanmıştır. Verilerin tablo haline dönüştürülmesinde, incelenen her lisansüstü tez için erişilen veri tabanına göre bir kod kullanılmıştır (Örneğin; YTYL1: YÖK Tez Yüksek Lisans 1 numaralı tez; YTDR2: YÖK Tez Doktora 2 numaralı tez; PQMD1: ProQuest Master Degree 1 numaralı tez; PQDD3: Doctorate Degree 3 numaralı tez vb.).

Içerik analizinde geçerliğin sağlanabilmesi, çalışmanın amaçları ile araçları arasındaki uyuma bağlı olmakta (Bilgin, 2006, s.17; Gökçe, 2006, s.83) bu da kategorilerin, araştırmacılar tarafından iyi tanımlanmıs olmasını gerektirmektedir. Güvenirlik ise kategorilere bağlı olarak kodlama işlemiyle gerçekleştirilmekte, kategorilerin oluşturulması ve açıkça çerçevelerinin belirlenmesi önem taşımaktadır (Gökçe, 2006, s.83). Bu doğrultuda, geçerlik ve güvenirliğin sağlanmasında, kuramsal bilgi temel alınarak kategoriler belirlenmiş, araştırmanın amaçlarına uygun olarak çalışmaya dâhil edilen lisansüstü tezlerin kodlanması için araştırmacılar tarafından "Lisansüstü Tez İnceleme Formu" geliştirilmiştir. Bu form geliştirilirken daha önce yapılan çalışmalar gözden geçirilmiş ve lisansüstü tezlerin içerik açısından detaylandırılması için benzer çalışmaların veri toplama araçları dikkatle incelenmiştir. Geliştirilen bu formda yazar, tez yılı, tez türü, alan, tez başlığı, amacı, araştırmanın türü, veri seti, veri toplama tekniği ile veri toplama aracı hakkında bilgilere yer verilmiştir. Lisansüstü tezlerin incelenmesi sürecinde kodlama için Microsoft Excel tablosu kullanılmış ve ayrıca çalışmaya dâhil edilen tüm veriler ile tablolaştırılan bilgiler daha sonraki dönemlerde olası bir onaylama talebine yönelik olarak saklanmıştır. Veriler, oluşturulan forma araştırmacılar tarafından ayrı ayrı girilmiş, bu şekilde kodlayıcı tutarlıı̆̆ı sağlanmaya çalışılmıştır. İçerik analizi ile çözümlenen veriler, temalara göre gruplanmış, yüzde (\%) ve frekans (f) değerleri verilerek sayısal hale dönüştürülmüş, tablolaştırılarak bulgular kısmında sunulmuştur.

\section{Bulgular}

Çalışmanın bu bölümünde yurt içi ve yurt dışında erken okuryazarlık alanında yapılan lisansüstü tezlerin incelenmesi amacıyla elde edilen bulgulara yer verilmiş; lisansüstü tezlerin türlerine, amaçlarına, çalışma gruplarına, kullanılan araştırma yöntemlerine-desenlerine ve veri toplama araçlarına yönelik betimsel bulgular, araştırma yapılan veri tabanlarına ve yıllara göre dağılımları göz önüne alınarak sunulmuştur.

Çalışmaya dahil edilen YÖK Veri Tabanından 33 adet ve ProQuest Veri Tabanından 40 adet olmak üzere toplam 73 lisansüstü tezin tamamı eğitim-öğretim konu alanı kapsamında yer almış, 20152020 yılları arasında ülkemizde yapılan lisansüstü tezlerden 5'inin eğitim-öğretim alanı ile birlikte farklı bilim alanlarının kapsamında da olduğu tespit edilmiştir. Bunların psikoloji (Enerem, 2018; Mutlu 2018), psikiyatri (Gürel, 2018) ve kulak burun boğaz (Saatçi, 2019; Sezgin, 2019) alanlarında gerçekleştirildiği ve eğitim-öğretim konu alanıyla direkt ilgili olmadıkları görülmüş, örneklem dışında bırakılmalarının uygun olacağı kararlaştırılmıştır. Bir lisansüstü tezi de eğitim-öğretim konu alanında yer almasına rağmen yabancı dil okuryazarlığına ilişkin öğretmen yeterliklerine (Sarı, 2019) yönelik yapılmış olması nedeniyle çalışma grubuna dâhil edilmemiş ve erişime açık durumdaki toplam 73 lisansüstü tez içerik açısından incelenmiştir.

Tablo 1'de YÖK ve ProQuest Veri Tabanlarında eğitim-öğretim konu alanında erken okuryazarlıkla ilgili gerçekleştirilmiş lisansüstü tezlerin yıllara ve türlerine göre dağılımları verilmiştir. 
Tablo 1.

Erken okuryazarlık alanında yapılmış lisansüstü tezlerin türlerine göre dağılımı

\begin{tabular}{|c|c|c|c|c|c|c|c|c|c|c|c|c|c|c|}
\hline & \multicolumn{7}{|c|}{ Yök Veri Tabanı } & \multicolumn{7}{|c|}{ Proquest Veri Tabanı } \\
\hline & $\stackrel{\sim}{\stackrel{n}{0}}$ & $\begin{array}{l}0 \\
\stackrel{\gamma}{\circ}\end{array}$ & 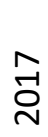 & $\stackrel{\infty}{\stackrel{\infty}{\circ}}$ & 융 & 옹 & $\frac{\frac{\varepsilon}{\pi}}{\frac{0}{0}}$ & $\stackrel{\text { 뭉 }}{\stackrel{\gamma}{N}}$ & $\begin{array}{l}0 \\
\stackrel{\sim}{0}\end{array}$ & 공 & $\stackrel{\infty}{\stackrel{\infty}{\circ}}$ & $\stackrel{\sigma}{\stackrel{\sigma}{0}}$ & 으 & $\frac{\frac{\varepsilon}{\sigma}}{\frac{0}{0}}$ \\
\hline Yüksek Lisans & 2 & 2 & 5 & 8 & 7 & 1 & 25 & 0 & 1 & 1 & 1 & 1 & 1 & 5 \\
\hline Doktora & 0 & 3 & 0 & 2 & 3 & 0 & 8 & 4 & 4 & 10 & 10 & 5 & 2 & 35 \\
\hline
\end{tabular}

Tablo 1 incelendiğinde, araştırmaya dâhil edilen 73 lisansüstü tezden 30'unun yüksek lisans, 43'ünün ise doktora eğitimi kapsamında gerçekleştirildiği görülmektedir. Yıllara göre dağılıma bakıldığında 2015 ve 2020 yılları arasında erken okuryazarlıkla ilgili olarak ülkemizde yüksek lisans tezinin ( $n=25)$, yurt dışında ise doktora tezinin $(n=35)$ sayısal olarak daha fazla olduğu tespit edilmiştir. Dolayısıyla yurt içindeki tez çalışmalarının daha çok yüksek lisans seviyesinde kaldığı, daha derinlemesine ve kapsamlı araştırmaların yapıımasını gerektiren doktora tez çalışmalarının ise sayıca az olduğu görülmüştür. Bunun aksine ProQuest Veri Tabanından elde edilen sonuçlar incelendiğinde doktora düzeyinde gerçekleştirilen çalışmaların sayısal olarak daha fazla olduğu bulunmuştur. Gelişimin her alanında kritik bir süreç olarak kabul edilen erken çocukluk döneminde, erken okuryazarlık kavramının önemi göz önüne alınarak doktora düzeyinde çalışmaların ülkemizde de daha çok yapılmasına gereksinim duyulmaktadır. 2020 yılına ait sayısal veriler incelendiğinde, ülkemizde 1 yüksek lisans tezinin tamamlandığı bulunmuş, yurt dışında ise 3 lisansüstü tezden 2'sinin doktora düzeyinde olduğu görülmüştür. Ancak 2020 Nisan ayı sonunda gerçekleştirilen son tarama sonrasında tamamlanan ve veri tabanına yerleştirilen lisansüstü tezlerin olacağı ihtimali de mevcuttur.

Erken okuryazarlık alanında 2015-2020 yılları arasında yapılan 73 lisansüstü tez çalışmasının amaçlarına göre dağılımları Tablo 2'de gösterilmiştir.

Tablo 2.

Erken okuryazarlık alanında yapılan lisansüstü tezlerin amaçlarına göre dağııımı

\begin{tabular}{|c|c|c|c|c|c|}
\hline \multirow[t]{2}{*}{ Amaçlar } & \multirow[t]{2}{*}{ Tezler } & \multicolumn{2}{|c|}{$\begin{array}{c}\text { Yök Veri } \\
\text { Tabanından } \\
\text { Alınan } \\
\text { Lisansüstü } \\
\text { Tezler }\end{array}$} & \multicolumn{2}{|c|}{$\begin{array}{l}\text { Proquest Veri } \\
\text { Tabanından } \\
\text { Alınan } \\
\text { Lisansüstü } \\
\text { Tezler }\end{array}$} \\
\hline & & $\mathrm{F}$ & $\%$ & $\mathrm{~F}$ & $\%$ \\
\hline $\begin{array}{l}\text { Paylaşımlı, etkileşimli, kılavuzlu } \\
\text { kitap okuma yönteminin erken } \\
\text { okuryazarlık becerilerine } \\
\text { etkisinin incelenmesi }\end{array}$ & $\begin{array}{c}\text { YTYL4, YTYL12, YTYL14, } \\
\text { YTYL17, YTYL33, YTDR1, } \\
\text { PQMD18, PQDD12, } \\
\text { PQDD13, PQDD22, PQDD29 }\end{array}$ & 6 & 18,18 & 5 & 12,50 \\
\hline $\begin{array}{l}\text { Erken okuryazarlık } \\
\text { programlarının çocukların erken } \\
\text { okuryazarlık becerilerine } \\
\text { etkisinin incelenmesi }\end{array}$ & $\begin{array}{c}\text { YTYL32, YTYL27, YTDR8, } \\
\text { YLDR18, PQMD25, PQDD11, } \\
\text { PQDD20, PQDD26, } \\
\text { PQDD37, PQDD38 }\end{array}$ & 4 & 12,12 & 6 & 15,00 \\
\hline $\begin{array}{l}\text { Erken okuryazarlık becerilerinin } \\
\text { ev ortamında desteklenmesi }\end{array}$ & $\begin{array}{l}\text { YTYL31, YTYL21, YTYL22, } \\
\text { YTYL23, YTDR2, YTDR3, } \\
\text { PQMD4, PQDD34, PQDD35, } \\
\text { PQDD36 }\end{array}$ & 6 & 18,18 & 4 & 10,00 \\
\hline $\begin{array}{l}\text { Yetişkinlerin } \\
\text { (Öğretmen/Yönetici/Öğretim }\end{array}$ & $\begin{array}{l}\text { YTYL6, YTYL11, YTYL15, } \\
\text { YTYL19, YTYL24, YTYL26, }\end{array}$ & 6 & 18,18 & 9 & 22,50 \\
\hline
\end{tabular}




\begin{tabular}{|c|c|c|c|c|c|}
\hline $\begin{array}{l}\text { Elemanı/Ebeveyn) erken } \\
\text { okuryazarlığa ilişkin algılarının, } \\
\text { görüşlerinin, inançlarının } \\
\text { belirlenmesi, uygulamalarının } \\
\text { incelenmesi }\end{array}$ & $\begin{array}{l}\text { PQDD19, PQMD39, PQDD7, } \\
\text { PQDD8, PQDD23, PQDD24, } \\
\text { PQDD27, PQDD33, PQDD40 }\end{array}$ & & & & \\
\hline $\begin{array}{l}\text { Risk altındaki çocukların (özel } \\
\text { gereksinimli, göçmen, köyde } \\
\text { yaşayan vb.) erken okuryazarlık } \\
\text { becerilerinin incelenmesi, } \\
\text { değerlendirilmesi geliştirilmesi }\end{array}$ & $\begin{array}{c}\text { YTYL5, YTYL13, YTYL20, } \\
\text { YTYL25, YTYL30, PQDD1, } \\
\text { PQDD16, PQDD17, PQDD31 }\end{array}$ & 5 & 15,15 & 4 & 10,00 \\
\hline $\begin{array}{l}\text { Dijital uygulamaların (kitap, } \\
\text { oyun, uygulama vs.) çocukların } \\
\text { erken okuryazarlık gelişimlerine } \\
\text { etkisinin incelenmesi }\end{array}$ & PQDD3, PQDD6, PQDD15 & 0 & 0,00 & 3 & 7,50 \\
\hline $\begin{array}{l}\text { İlkokul birinci sınıf } \\
\text { öğrencilerinin okuma } \\
\text { becerilerinin çok yönlü } \\
\text { desteklenmesi }\end{array}$ & YTDR7 & 1 & 3,03 & 0 & 0,00 \\
\hline $\begin{array}{l}\text { Okuma yazmaya hazır } \\
\text { bulunuşluğu belirleme aracının } \\
\text { geliştirilmesi }\end{array}$ & YTDR9 & 1 & 3,03 & 0 & 0,00 \\
\hline $\begin{array}{l}\text { Oyun ve erken okuryazarlık } \\
\text { arasındaki ilişkinin incelenmesi }\end{array}$ & YTYL10, PQDD30 & 1 & 3,03 & 1 & 2,50 \\
\hline $\begin{array}{l}\text { Erken okuryazarlık ile kronolojik } \\
\text { yaş-gelişim/beceri ilişkisi }\end{array}$ & $\begin{array}{l}\text { YTYL16, YTYL28, YTYL29, } \\
\text { PQDD10, PQDD32 }\end{array}$ & 3 & 9,10 & 2 & 5,00 \\
\hline $\begin{array}{l}\text { Malta devlet okullarındaki } \\
\text { erkek çocukların yaşadığı erken } \\
\text { okuma yazma deneyimlerinin } \\
\text { araştırılması }\end{array}$ & PQDD5 & 0 & 0,00 & 1 & 2,50 \\
\hline $\begin{array}{l}\text { Erken okuryazarlık müdahale } \\
\text { hizmetlerine duyulan ihtiyacın } \\
\text { incelenmesi }\end{array}$ & PQMD9 & 0 & 0,00 & 1 & 2,50 \\
\hline \multirow[t]{2}{*}{$\begin{array}{l}\text { Erken okuryazarlık becerilerinin } \\
\text { etkileyen faktörlerin } \\
\text { incelenmesi }\end{array}$} & $\begin{array}{c}\text { PQDD2, PQDD14, PQDD21, } \\
\text { PQDD28 }\end{array}$ & 0 & 0,00 & 4 & 10,00 \\
\hline & Toplam & 33 & 100,00 & 40 & 100,00 \\
\hline
\end{tabular}

Tablo 2 incelendiğinde 2015-2020 yıllarında, erken okuryazarlık alanına yönelik yapılan lisansüstü tez çalışmalarının farklı amaçlarla gerçekleştiği görülmektedir. Buna göre "yetişkinlerin (öğretmen / yönetici / öğretim elemanı / ebeveyn) erken okuryazarlığa ilişkin algılarının, görüşlerinin, inançlarının belirlenmesi, uygulamalarının incelenmesi" amacıyla gerçekleştirilen lisansüstü tezlerin $\% 40,68$ ile en yüksek frekansa sahip olduğu bulunmuştur. Bununla birlikte incelenen lisansüstü tezlerin \%30,68'inde "paylaşımlı, etkileşimli, kılavuzlu kitap okuma yönteminin erken okuryazarlık becerilerine etkisinin incelenmesi", \%27,12'sinde ise "erken okuryazarlık programlarının çocukların erken okuryazarlık becerilerine etkisinin incelenmesi" amaçlanmıştır. Buna karşın "erken okuryazarlık müdahale hizmetlerine duyulan ihtiyacın incelenmesi" ve "Malta devlet okullarındaki erkek çocukların yaşadığı erken okuma yazma deneyimlerinin araştırılması" amaçlı doktora düzeyindeki tez çalışmalarının da \%2,50 ile en düşük frekansa sahip olduğu tespit edilmiştir.

Erken okuryazarlık alanında 2015-2020 yılları arasında yapılmış olan tezlerin çalışma gruplarına göre dağılımlarına Tablo 3'te yer verilmiştir. 
Tablo 3.

Erken okuryazarlık alanında yapılmış lisansüstü tezlerde yer verilen çalışma gruplarının dağılımı

\begin{tabular}{|c|c|c|c|c|c|c|c|c|c|c|c|c|c|c|}
\hline & \multicolumn{7}{|c|}{ Yök Veri Tabanı } & \multicolumn{7}{|c|}{ Proquest Veri Tabanı } \\
\hline & $\stackrel{\text { 뮤 }}{\stackrel{\sim}{\sim}}$ & $\begin{array}{l}0 \\
\stackrel{-}{0} \\
\sim\end{array}$ & 국 & $\stackrel{\infty}{\stackrel{\infty}{\circ}}$ & 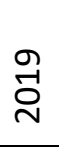 & ণ্ণ & $\begin{array}{l}\frac{\varepsilon}{\pi} \\
\frac{\pi}{0} \\
0 \\
\vdash\end{array}$ & $\stackrel{\text { 모 }}{\stackrel{\sim}{\sim}}$ & $\begin{array}{l}0 \\
\stackrel{1}{0} \\
\sim\end{array}$ & 귱 & $\stackrel{\infty}{\stackrel{\infty}{\circ}}$ & 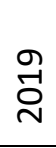 & ণ্ণ & $\frac{\frac{\varepsilon}{\pi}}{\frac{\pi}{0}}$ \\
\hline Çocuk & 0 & 5 & 4 & 8 & 8 & 1 & 26 & 4 & 1 & 4 & 8 & 2 & 2 & 21 \\
\hline Öğretmen & 1 & 1 & 1 & 1 & 2 & 0 & 6 & 0 & 1 & 6 & 3 & 3 & 1 & 14 \\
\hline Aile & 1 & 2 & 1 & 5 & 4 & 0 & 13 & 1 & 1 & 4 & 3 & 3 & 0 & 12 \\
\hline Yönetici & 0 & 0 & 0 & 0 & 0 & 0 & 0 & 0 & 1 & 1 & 1 & 2 & 0 & 5 \\
\hline Öğretim Elemanı & 0 & 0 & 0 & 0 & 0 & 0 & 0 & 0 & 0 & 1 & 0 & 0 & 0 & 1 \\
\hline
\end{tabular}

Tablo 3 incelendiğinde çocuk, aile, öğretmen/öğretim elemanı ve yönetici olmak üzere dört grupla erken okuryazarlık lisansüstü tez çalışmaların gerçekleştirildiği tespit edilmiştir. Ülkemizde en çok çalışılan örneklem grubunun sırayla 3-7 yaş aralığındaki çocuklar, aileler ve öğretmenler; yurt dışında ise çocuklar, öğretmen/öğretim elemanları, aileler ve yöneticiler olduğu belirlenmiştir. Ayrıca bazı çalışmalarda (YTDR2, YTDR3, YTYL6, YTDR7, YTYL17, YTYL22, YTYL23, YTYL29, PQDD8, PQDD11, PQDD21, PQDD22, PQDD24, PQMD25, PQDD27, PQDD30, PQDD32, PQDD38, PQDD40) araştırmacıların; çocuk ve aile, çocuk ve öğretmen ya da çocuk, aile ve öğretmen gibi birden fazla çalışma grubu ile araştırma yaptıkları tespit edilmiştir.

Elde edilen bulgular doğrultusunda çocuklarla doğrudan yapılan çalışmaların sayısının fazla olduğu ( $n=47)$ görülmüştür. Yıllara göre dağılım incelendiğinde, ülkemizde 2018 ve 2019 yıllarında çocuk grubuyla yapılan çalışmaların sayıca fazla olduğu $(n=16)$ bulunmuş, yurt dışında ise sadece 2018 yılında gerçekleştirilen lisansüstü tezlerde bu gruba ağırlık verildiği $(n=8)$ tespit edilmiştir. Ülkemizde yöneticilerle gerçekleştirilen lisansüstü tez çalışmasının bulunmadığı, yurt dışında ise 2016-2019 yılları arasında bu grupla yapılan lisansüstü tezlerin sayıca fazla olduğu $(n=5)$ görülmüştür. Belirlenen çalışma grupları arasında en az sayıda $(n=1)$ çalışılan grubun ise öğretim elemanları olduğu tespit edilmiş, bu çalışmanın da 2017 yılında yurt dışında doktora düzeyinde gerçekleştirildiği (PQDD40) saptanmıştır.

Lisansüstü tezlerde kullanılan yöntemler üç grupta incelenmiş ve dağılımları Tablo 4'te gösterilmiştir.

Tablo 4.

Erken okuryazarlık alanında yapılmış lisansüstü tezlerde kullanılan araştırma yöntemlerinin dağılımı Yök Veri Tabanı Proquest Veri Tabanı

\begin{tabular}{|c|c|c|c|c|c|c|c|c|c|c|c|c|c|}
\hline & 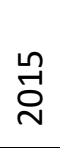 & $\begin{array}{l}0 \\
\stackrel{\sim}{\sim} \\
\stackrel{\sim}{ }\end{array}$ & 귱 & $\stackrel{\infty}{\stackrel{\infty}{\sim}}$ & 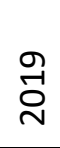 & 유 & $\begin{array}{l}\frac{\varepsilon}{\pi} \\
\frac{\pi}{0} \\
\frac{0}{0}\end{array}$ & $\stackrel{n}{\stackrel{n}{\gamma}}$ & $\begin{array}{l}\stackrel{0}{ } \\
\stackrel{\circ}{\circ}\end{array}$ & 穴 & $\stackrel{\infty}{\stackrel{\infty}{\circ}}$ & $\stackrel{\text { 뭉 }}{\stackrel{\gamma}{ }}$ & ্ָণ \\
\hline Nitel Desen & 0 & 0 & 1 & 3 & 0 & 0 & 4 & 2 & 3 & 6 & 5 & 4 & 1 \\
\hline Nicel Desen & 2 & 5 & 3 & 7 & 8 & 1 & 26 & 0 & 1 & 3 & 4 & 2 & 1 \\
\hline Karma Desen & 0 & 0 & 1 & 0 & 2 & 0 & 3 & 2 & 1 & 2 & 2 & 0 & 1 \\
\hline
\end{tabular}

Tablo 4 incelendiğinde, YÖK Veri Tabanında kayıtlı lisansüstü tezlerden 26'sının nicel, 4'ünün nitel ve 3 'ünün karma yöntemle yapıldığı; ProQuest Veri Tabanında yer alan lisansüstü tezlerden ise 
$21^{\prime}$ inin nitel, $11^{\prime}$ inin nicel ve 8'inin karma araştırma yöntemine sahip olduğu görülmektedir. Yıllara göre dağılıma bakıldığında 2019 yılında ülkemizde yapılan lisansüstü tezlerde kullanılan nicel yöntemin sayıca fazla $(n=8)$ olduğu bulunmuş, buna karşın aynı yılda, aynı yöntem kullanılarak yurt dışında gerçekleştirilmiş tez sayısının daha düşük $(n=2)$ olduğu tespit edilmiştir. Bunun yanı sıra ProQuest Veri Tabanında 2017 yılında nitel araştırma yöntemiyle yapılan 6 lisansüstü tez çalışmasına karşın ülkemizde aynı yılda, aynı araştırma yöntemiyle sadece bir lisansüstü tez çalışmasının olduğu bulunmuştur. Bu bulgular ışığında erken okuryazarlık ile ilgili ülkemizde yapılan lisansüstü tezlerde nicel araştırma yöntemlerinin, yurt dışında ise nitel araştırma yöntemlerinin daha ağırlıklı kullanıldığı görülmüş, karma yöntem kullanılarak gerçekleştirilen lisansüstü tez çalışmalarının ise ülkemize $(n=3)$ kıyasla yurt dışında daha fazla $(n=8)$ tercih edildiği saptanmıştır.

Tablo 5'de incelenen lisansüstü tezlerde kullanılan araştırma desenlerinin dağılımına yer verilmiştir.

Tablo 5.

Erken okuryazarlık alanında yapılan lisansüstü tezlerde kullanılan araştırma desenlerinin dağılımı

\begin{tabular}{|c|c|c|c|c|c|}
\hline \multirow[t]{2}{*}{$\begin{array}{l}\text { Araştırma } \\
\text { Desenleri }\end{array}$} & \multirow[t]{2}{*}{ Tezler } & \multicolumn{2}{|c|}{$\begin{array}{l}\text { Yök Veri } \\
\text { Tabanından } \\
\text { Alınan } \\
\text { Lisansüstü } \\
\text { Tezler } \\
\end{array}$} & \multicolumn{2}{|c|}{$\begin{array}{c}\text { Proquest Veri } \\
\text { Tabanından Alınan } \\
\text { Lisansüstü Tezler }\end{array}$} \\
\hline & & f & $\%$ & $\mathrm{~F}$ & $\%$ \\
\hline Tarama & $\begin{array}{l}\text { YTYL6, YTYL13, YTYL15, YTYL16, YTYL19, } \\
\text { YTYL20, YTYL21, YTYL22, YTYL23, YTYL25, } \\
\text { YTYL26, YTYL28, YTYL29, YTYL30, YTYL31, } \\
\text { YTDR2, YTDR9, PQMD39, PQDD1, PQDD14, } \\
\text { PQDD16, PQDD21, PQDD23, PQDD28, } \\
\text { PQDD31, PQDD32, PQDD38 }\end{array}$ & 17 & 51,52 & 10 & 25,00 \\
\hline Deneysel & $\begin{array}{c}\text { YTYL4, YTYL10, YTYL12, YTYL14, YTYL27, } \\
\text { YTYL32, YTDR1, YTDR8, YTDR18, YTDR33, } \\
\text { PQDD3, PQDD5, PQDD6, PQDD10, } \\
\text { PQDD12, PQDD13, PQDD17, PQMD18, } \\
\text { PQDD22, PQMD25, PQDD26, PQDD33, } \\
\text { PQDD35, PQDD37 }\end{array}$ & 10 & 30,30 & 14 & 35,00 \\
\hline $\begin{array}{l}\text { Durum } \\
\text { Çalışması }\end{array}$ & YTYL5, PQMD4 & 1 & 3,03 & 1 & 2,50 \\
\hline $\begin{array}{l}\text { Vaka } \\
\text { Çalışması }\end{array}$ & $\begin{array}{l}\text { PQDD8, PQDD11, PQDD15, PQDD19, } \\
\text { PQDD24, PQDD27, PQDD29, PQDD34, } \\
\text { PQDD36, PQDD40 }\end{array}$ & 0 & 0,00 & 10 & 25,00 \\
\hline $\begin{array}{l}\text { Eylem } \\
\text { Araştırması }\end{array}$ & YTDR7, YTYL11, YTYL17, PQDD7 & 3 & 9,09 & 1 & 2,50 \\
\hline $\begin{array}{l}\text { Boylamsal } \\
\text { Araştırma }\end{array}$ & YTYL3 & 1 & 3,03 & 0 & 0,00 \\
\hline $\begin{array}{l}\text { Etnografik } \\
\text { Araştırma }\end{array}$ & PQDD2, PQDD30 & 0 & 0,00 & 2 & 5,00 \\
\hline $\begin{array}{l}\text { Doküman } \\
\text { İncelemesi }\end{array}$ & YTYL24, PQMD9 & 1 & 3,03 & 1 & 2,50 \\
\hline Olgubilim & PQDD20 & 0 & 0,00 & 1 & 2,50 \\
\hline & Toplam & 33 & 100,00 & 40 & 100,00 \\
\hline
\end{tabular}

Tablo 5'de görüldüğü gibi erken okuryazarlık alanında yapılan lisansüstü tezlerin büyük bir kısmının ( $f=27$ ) tarama modelinde desenlendiği belirlenmiştir. Bu, geçmişte ya da halen var olan erken 
okuryazarlıkla ilgili durumun, var olduğu şekliyle betimlenmeye çalışıldığını göstermektedir. Tarama modelini takiben incelenen lisansüstü tezlerde sayısal olarak en fazla $(f=24)$ yer verilen araştırma deseninin deneysel desen olduğu görülmüştür. Bunu, yurt dışında ve sadece doktora düzeyinde gerçekleştirilen vaka çalışmalarının $(\mathrm{f}=10)$ izlediği tespit edilmiş, ülkemizde ise vaka çalışmasına yer veren hiç lisansüstü teze rastlanmamıştır. Bunlara karşın yurt dışı lisansüstü tez çalışmalarında olmamasına rağmen ülkemizde sadece bir yüksek lisans tezinde boylamsal araştırma desenine, ülkemizde gerçekleştirilen lisansüstü tezlerde hiç bulunmamasına rağmen yurt dışında sadece bir doktora tezinde de olgubilim desenine yer verilmiştir.

Erken okuryazarlık alanında yapılan lisansüstü tezlerde kullanılan veri toplama araçları Tablo 6'da gösterilmiştir.

Tablo 6.

Erken okuryazarlık alanında yapılan lisansüstü tezlerin veri toplama araçlarına göre dağılımı

\begin{tabular}{|c|c|c|c|c|c|}
\hline \multirow[t]{2}{*}{$\begin{array}{l}\text { Veri Toplama } \\
\text { Araçları }\end{array}$} & \multirow[t]{2}{*}{ Tezler } & \multicolumn{2}{|c|}{$\begin{array}{l}\text { Yök Veri } \\
\text { Tabanından } \\
\text { Alınan } \\
\text { Lisansüstü } \\
\text { Tezler } \\
\end{array}$} & \multicolumn{2}{|c|}{$\begin{array}{l}\text { Proquest Veri } \\
\text { Tabanından } \\
\text { Alınan } \\
\text { Lisansüstü } \\
\text { Tezler }\end{array}$} \\
\hline & & $f$ & $\%$ & $F$ & $\%$ \\
\hline Kişisel Bilgi Formu & $\begin{array}{c}\text { YTDR3, YTYL6, YTYL12, YTYL14, YTYL16, } \\
\text { YTDR18, YTYL19, YTYL22, YTYL23, } \\
\text { YTYL25, YTYL27, YTYL28, YTYL29, } \\
\text { YTYL30, YTYL31, YTYL32, PQMD18, } \\
\text { PQMD25, PQDD1, PQDD12, PQDD15, } \\
\text { PQDD15, PQDD28, PQDD34, PQDD35, } \\
\text { PQDD36, PQDD37, PQDD38 }\end{array}$ & 16 & 23,18 & 12 & 13,64 \\
\hline Görüşme & $\begin{array}{c}\text { YTYL5, YTYL6, YTYL10, YTYL11, YTYL17, } \\
\text { YTYL26, YTDR7, PQMD18, PQMD25, } \\
\text { PQMD39, PQDD1, PQDD2, PQDD3, } \\
\text { PQDD5, PQDD6, PQDD7, PQDD8, } \\
\text { PQDD11, PQDD15, PQDD16, PQDD17, } \\
\text { PQDD20, PQDD24, PQDD27, PQDD29, } \\
\text { PQDD30, PQDD31, PQDD33, PQDD36, } \\
\text { PQDD38, PQDD40 }\end{array}$ & 7 & 10,14 & 24 & 27,27 \\
\hline Gözlem & $\begin{array}{l}\text { YTYL5, YTYL11, YTYL14, YTDR3, YTDR7, } \\
\text { PQMD18, PQDD1, PQDD2, PQDD3, } \\
\text { PQDD5, PQDD7, PQDD8, PQDD11, } \\
\text { PQDD15, PQDD19, PQDD22, PQDD28, } \\
\text { PQDD29, PQDD30, PQDD38, PQDD40 }\end{array}$ & 5 & 7,25 & 16 & 18,18 \\
\hline Anket & $\begin{array}{c}\text { YTYL15, YTYL19, YTYL23, YTDR2, } \\
\text { YTDR3, PQMD4, PQMD39, PQDD5, } \\
\text { PQDD6, PQDD21, PQDD23, PQDD30, } \\
\text { PQDD33, PQDD35 }\end{array}$ & 5 & 7,25 & 9 & 10,22 \\
\hline Ölçek & $\begin{array}{l}\text { YTYL4, YTYL6, YTYL10, YTYL12, YTYL13, } \\
\text { YTYL14, YTYL16, YTYL19, YTYL20, } \\
\text { YTYL22, YTYL23, YTYL24, YTYL25, } \\
\text { YTYL26, YTYL27, YTYL28, YTYL29, } \\
\text { YTYL30, YTYL31, YTYL32, YTDR1, } \\
\text { YTDR2, YTDR3, YTDR8, YTDR9, YTDR18, } \\
\text { YTDR33, PQMD18, PQDD3, PQDD6, } \\
\text { PQDD8, PQDD10, PQDD12, PQDD13, }\end{array}$ & 28 & 40,58 & 12 & 13,64 \\
\hline
\end{tabular}


PQDD14, PQDD17, PQDD22, PQDD26, PQDD37

Alan Notları

YTYL17, YTDR1, YTDR7, PQDD1,

\begin{tabular}{|c|c|c|c|c|c|}
\hline Alan Notları & $\begin{array}{c}\text { PQDD2, PQDD7, PQDD8, PQDD34, } \\
\text { PQDD38 }\end{array}$ & 3 & 4,35 & 6 & 6,82 \\
\hline Araştırmacı Günlüğü & $\begin{array}{c}\text { YTYL5, YTYL11, YTYL17, YTDR7, } \\
\text { PQMD18, PQDD11, PQDD19, PQDD30, } \\
\text { PQDD34 }\end{array}$ & 4 & 5,80 & 5 & 5,68 \\
\hline Arşiv Kayıtları & PQDD28, PQDD32 & 0 & 0,00 & 2 & 2,27 \\
\hline $\begin{array}{l}\text { Erken Okuryazarlık } \\
\text { Programları }\end{array}$ & PQMD9 & 0 & 0,00 & 1 & 1,14 \\
\hline \multirow[t]{2}{*}{ Portfolyo } & YTYL11, PQDD1 & 1 & 1,45 & 1 & 1,14 \\
\hline & Toplam & 69 & 100,00 & 88 & 100,00 \\
\hline
\end{tabular}

*Çalışmaların bazılarında birden çok veri toplama aracı kullanıldığı için tabloda her bir türün frekans değeri, kullanıldı̆̆ı araştırma sayısına göre oluşturulmuştur. Bu nedenle analiz edilen toplam tez sayısı $(n=73)$ ile tabloda verilen frekansların toplamı birbirinden farklıdır.

Tablo 6'da görüldüğü gibi, erken okuryazarlık alanında ülkemizde yapılan lisansüstü tezlerin büyük çoğunluğunda veri toplama aracı olarak ölçek $(\% 40,58)$, yurt dışında gerçekleştirilen lisansüstü tezlerin çoğunluğunda ise görüşme $(\% 27,27)$ kullanılmıştır. Gerek ülkemizde $(\% 5,80)$, gerekse yurt dışında $(\% 5,68)$ lisansüstü tezlerde araştırmacı günlüklerinin benzer oranlarda kullanıldığı saptanırken, örnekleme dâhil edilen çalışma grubu hakkında detaylı bilgilerin elde edilmesine yönelik olarak kullanılan kişisel (aile ve çocuk) bilgi formunun ülkemizde $(\% 23,18)$, yurt dışı $(\% 13,64)$ lisansüstü tez çalışmalarına kıyasla daha yüksek oranda tercih edildiği görülmüştür. Bunların yanı sıra ülkemizde ve yurt dışında incelenen lisansüstü tezlerde kullanılan veri toplama araçları arasında gözlem $(\% 25,43)$ ve anket $(\% 17,47)$ kullanımının yüksek olduğu tespit edilmiş ancak gözlem kullanılan yurt dışı lisansüstü tez çalışmalarının $(\% 18,18)$, ülkemizdeki lisansüstü tez çalışmalarından $(\% 7,25)$ daha yüksek oranda olduğu da dikkat çekmiştir. Benzer şekilde anket kullanılan yurt dışı lisansüstü tez çalışmalarının oranı $(\% 10,22)$ da ülkemizdeki lisansüstü tez çalışmalarından $(\% 7,25)$ daha fazladır. Portfolyo, veri toplama aracı olarak ülkemizde yüksek lisans düzeyinde, yurt dışında doktora düzeyinde gerçekleştirilen birer lisansüstü tez çalışmasında kullanılmış, erken okuryazarlık müdahale hizmetlerine duyulan ihtiyacın giderilmesi için özel olarak geliştirilen erken okuryazarlık programına ise yurt dışında gerçekleştirilen tek bir lisansüstü tezinde veri toplama aracı olarak yer verilmiştir.

\section{Tartışma ve Sonuç}

Bu çalışma, erken okuryazarlık alanıyla ilgili 2015-2020 yılları arasında ülkemizde ve yurt dışında yapılan lisansüstü tezlerin araştırma eğilimlerinin belirlenmesi amacıyla gerçekleştirilmiştir. Bu doğrultuda YÖK Ulusal Tez Merkezi ile ProQuest Dissertations and Theses veri tabanlarından toplam 73 lisansüstü tez çalışmasına ulaşıımıştır. İncelenen yıllar içinde erken okuryazarlık alanında yurt içinde yapılan tezlerin büyük çoğunluğunun yüksek lisans düzeyinde gerçekleştirildiği, doktora düzeyinde yürütülen tezlerin daha az sayıda olduğu; yurt dışında ise doktora tezlerinin yüksek lisans tezlerine oranla daha fazla olduğu görülmüştür. Bu çalışmaların yıllara göre dağıımına bakıldığında ise ülkemizde 2018 ve 2019 yıllarında gerçekleştirilen yüksek lisans düzeyindeki tez sayılarının, yurt dışında aynı dönemlerde gerçekleştirilen doktora düzeyindeki tez çalışmalarına yakın olduğu saptanmıştır. Ancak niceliksel açıdan karşılaştırma yapmaktan ziyade akademik açıdan alana katkı sağlamaları ve daha derinlemesine çalışmaların yapılabilirliği açısından doktora düzeyinde gerçekleştirilen lisansüstü tezlerin, ülkemizde az sayıda yapılmış olması düşündürücü ve üzerinde hassasiyetle durulması gereken bir durumdur. Alanyazında erken çocukluk eğitimi alanında yapılan ve farklı konuları içeren lisansüstü tez çalışmalarında da yüksek lisans tez sayısının doktora tez sayısına oranla daha fazla olduğu bulgularına (Ahi \& Kıldan, 2013; Altun, Şendil \& Şahin, 2011; Can Yaşar \& Aral, 2011; Karaoğlu \& Esen Çoban, 2019; Kaytez \& Durualp, 2014) ulaşmışlardır. 
Incelenen lisansüstü tezlerin büyük çoğunluğunda "yetişkinlerin erken okuryazarlığa ilişkin algıları, görüşleri, inançları ve uygulamaları" amaçlanmış, bunu "paylaşımlı, etkileşimli, kılavuzlu kitap okuma yönteminin erken okuryazarlığa etkisi"ni belirleyen çalışmalar takip etmiştir. "Erken okuryazarlık programlarının etkileri ve bu programlar kullanılarak ev ortamında erken okuryazarlığın desteklenmesi" amaçlarıyla yapılan lisansüstü tez çalışmalarının da sayısal açıdan fazla olduğu bulunmuştur. Bu durum erken okuryazarlık kavramına ilişkin gerek yetişkinlerin bilgi, tutum ve beceri açısından kendilerini geliştirme çabası içerisinde olduklarını göstermek ve gerekse çocukların erken müdahale kapsamında yer verilen ev ortamlarında erken okuryazarlıkla tanışmalarını ve akademik açıdan daha donanımlı bir şekilde ilkokula başlamalarını sağlayarak gelecekteki akademik başarılarını desteklemek açılarından büyük önem taşımaktadır (Ergül, Dolunay Sarıca, Akoğlu \& Karaman, 2017; Gül, 2007; Işıkoğlu Erdoğan, 2016; Kınık, Okyay \& Aydoğan, 2016).

Araştırmada yer alan lisansüstü tezlerin çalışma grupları incelendiğinde gerek ülkemizde ve gerekse yurt dışında en çok çalışılan grubun çocuklar olduğu belirlenmiştir. Bu bulgu alanyazındaki diğer çalışmaların bulgularıyla da örtüşmektedir (Demirtaş ilhan, 2017; Özen Uyar \& Ormancı, 2016; Sarı \& Altun, 2018). Lisansüstü tezlerde çocuk çalışma gruplarındaki yaş aralı̆ıına bakıldığında, dağılımın üç ile yedi yaş aralığında yani erken çocukluk döneminde olduğu görülmektedir. Alanyazında bütünsel gelişimin 1-3 yaş arası dönemde çok yoğun kazanımlarla desteklenmesinin uygunluğuna yönelik araştırmaların olması (Haney \& Hill, 2004; Whitehurst \& Lonigan, 2001; Yarar \& İnan, 2015), 3 yaş sonrasında yapılan erken okuryazarlık çalışmalarının (Kargın, Güldenoğlu \& Ergül, 2017; Tercanlı Metin \& Gökçay, 2014) da çocukların bu alanda ivme kazanmalarını desteklemesi açısından önemli olduğunu düşündürmektedir. Ülkemizde yapılan lisansüstü tezlerde çocuklardan sonra sırayı aileler ve öğretmenler almakta, yurt dışında ise öğretmen/öğretim elemanı, aile ve yönetici, çocuk çalışma grubunu takip etmektedir. Dikkat çeken bir çalışma grubu olarak karşımıza çıkan yöneticiler, 2016 yılı ve sonrasında yurt dışında gerçekleştirilen lisansüstü tezlerde giderek artan bir ivme ile yerini almıştır. Ülkemizde ise yönetici grubuyla yapılmış herhangi bir lisansüstü tez çalışmasına rastlanmamıştır. Oysaki özellikle okul öncesi dönemde erken okuryazarlıkla ilgili öğretmen ve yöneticilerin inançlarına yönelik araştırmaların yapılması, erken okuryazarlık uygulamalarının bu düzeyde gerçekleştirilmesine kapı açacak önemli bir yol olarak düşünülmektedir. Bir diğer dikkat çeken husus ise incelenen yıllar arasında yükseköğretimde görev yapan öğretim elemanlarıyla gerçekleştirilen yalnızca bir doktora düzeyinde lisansüstü tez çalışmasının, yurt dışında yapıımış olmasıdır. Bilim üretme merkezi olarak kabul edilen üniversitelerdeki öğretim elemanlarının erken okuryazarlık konusundaki görüşlerini/düşüncelerini inceleyen çalışmaların çok az sayıda olması ve farklı alanlarda gerçekleştirilen araştırmalarda da (Dündar \& Hareket, 2017; Oğuz Haçat \& Demir, 2019) benzer sonuçlara yer verilmesi, gelecekte bu çalışma grubuyla yeni araştırmaların planlanması gerekliliğini gözler önüne sermektedir.

Erken okuryazarlık alanında ülkemizde gerçekleştirilen çalışmalar incelendiğinde lisansüstü tezlerde nicel araştırma yöntemlerinin sayısal olarak daha çok kullanıldığı görülmüştür. Ülkemizde okul öncesi ve eğitim alanında yapılan lisansüstü tez çalışmalarında da nicel araştırma yöntemlerinin daha fazla tercih edildiğine ilişkin bulgular, alanyazındaki diğer çalışmalarda da mevcuttur ve çalışmamızı destekler niteliktedir (Bahçacı \& Türkoğlu, 2019; Gürsoy, Aydoğdu, Aysu \& Aral, 2019; Oğuz Haçat \& Demir, 2019; Özen Uyar \& Ormancı, 2016; Sarı \& Altun, 2018). Yurt dışında gerçekleştirilen lisansüstü tezlerde ise daha çok nitel araştırma yöntemlerine yer verildiği bulunmuş ayrıca hem nitel hem de nicel araştırma yöntemlerinin bir arada kullanıldığı karma yöntemiyle gerçekleştirilen çalışmaların, ülkemizdeki lisansüstü tezlere göre fazla olduğu tespit edilmiştir. Bu durumun ülkemizde yapılan akademik çalışmalarda kullanılan araştırma yöntemlerine ilişkin bilgilerin eksikliğinden ve öğretim elemanlarının bu konudaki yetkinliklerinin sınırlılı̆ından kaynaklandığı düşünülmektedir. 2015-2020 yılları arasında yapılan tezler incelendiğinde Türkiye'de veri toplama aracı olarak ölçeklerin kullanılması yoluyla gerçekleştirilen araştırmalarda nicel paradigmaların daha çok benimsendiği; yurt dışında ise görüşme, gözlem ve araştırmacı notları gibi veri toplama araçlarıyla derinlemesine bilgi edinmeyi sağlayan nitel araştırma yaklaşımlarııın daha çok kullanıldığı görülmektedir. Sarı ve Altun (2018) da erken okuryazarlık üzerine yapılan tezleri ve makaleleri inceledikleri çalışmasında en çok kullanılan veri toplama araçlarının, ölçek ve görüşmeler olduğunu belirtmişlerdir. Ayrıca tüm araştırmalarda ortak olan tek veri toplama aracının, her araştırmanın amacına bağlı olarak geliştirilen kişisel bilgi formu 
olduğu gözlenmiştir. Lisansüstü tezlerde kullanılan araştırma yöntemleri ile veri toplama araçları bütün olarak değerlendirildiğinde ise ülkemizde niteliksel çalışmaların göz ardı edildiği, standart ölçme araçları arasında yer alan ölçeklerin ve anketlerin diğer veri toplama araçlarına göre daha fazla kullanıldığı (Karadağ, 2014), bunun da daha nesnel puanlamanın yapılması ve kısa zamanda daha çok kişiye ulaşılmasını sağlaması nedenleriyle tercih edildiği düşünülmektedir. Ayrıca bu ölçme araçlarının uygulayıcılara zaman ve çaba açısından da ekonomi sağlaması, tercih nedenleri arasında sıralanabilir. Yurt dışında yapılan lisansüstü tez çalışmalarında ise nitel araştırma yöntemlerinin kullanılmasının ve gözlem ile görüşmeye daha fazla oranda yer verilmesinin kolay ve hızlı bir biçimde uygulanabilmesi ve daha da önemlisi konu hakkında derinlemesine bilgi edinilebilmesi açılarından tercih edildiği düşünülmektedir.

Araştırma desenleri açısından lisansüstü tezler incelendiğinde de ülkemizde yapılan çalışmaların büyük çoğunluğunda tarama modeli kullanılmış, erken okuryazarlıkla ilgili mevcut durumun betimlenmesine yönelik çalışmalar gerçekleştirilmiştir. Yurt dışında gerçekleştirilen lisansüstü tezler incelendiğinde ise bu çalışmaların büyük çoğunluğunda deneysel desene yer verildiği ve vaka çalışmalarının kullanıldığı görülmektedir. Bu bilgiler ışığında ülkemizde 2015-2020 yılları arasında yapılan lisansüstü tezlerde genellikle var olan durumun betimlenmesine yönelik çalışmaların olduğu, yurt dışı lisansüstü tezlerde kullanılan vaka çalışmalarına, etnografik araştırmalara ve olgubilim çalışmalarına ise hiç yer verilmediği bulunmuştur. Erken okuryazarlık konu alanında yapılan lisansüstü tezlerde kullanılan araştırma yöntem ve desenleri ile veri toplama araçları geniş bir perspektiften ele alındığında, yurt dışı lisansüstü tezlere kıyasla ülkemizde çok daha dar kapsamlı araştırmaların gerçekleştirildiği ve bu durumun öğretim elemanlarının araştırma yöntemleri konusundaki bilgileriyle sınırlı olduğu düşünülmekte, bu durumun farklı alanlarda gerçekleştirilen çalışmalarda da vurgulandığı görülmektedir (Sarı \& Altun, 2018; Yazıcı \& Kandır, 2018).

Erken okuryazarlık alanında ülkemizde ve yurt dışında gerçekleştirilmiş lisansüstü tezlerin incelendiği bu araştırmada elde edilen bulgular sonucunda, Türkiye'de bu alanda doktora düzeyinde yapılan çalışmaların azlığı dikkati çekmekte ve konunun bu düzeyde ele alınarak daha derinlemesine çalışılması gerektiği düşünülmektedir. Ayrıca ülkemizde yöneticilerin ve üniversite öğretim elemanlarının dâhil edildikleri erken okuryazarlık araştırmalarına ihtiyaç da gözler önüne serilmiş, bu konuda ileriye dönük çalışmaların planlanması gerektiği ortaya konmuştur. Elde edilen sonuçlara dayanarak erken okuryazarlık alanında daha derinlemesine bilgi toplamak amacıyla nicel ve nitel yöntemlerin birlikte kullanıldığı karma yöntemin tercih edilmesinin ve aynı zamanda boylamsal araştırmalar ve eylem araştırmaları gibi araştırma desenlerin yer verilmesinin alana, çocuklara ve dolayısıyla geleceğe daha fazla katkı sağlayacağı düşünülmektedir.

Bu çalışma 2015-2020 yılları arasında ülkemizde ve yurt dışında yapılan lisansüstü tezler ile sınırlıdır. Çalışmanın kapsamı genişletilerek daha ayrıntılı bilgi elde edilebilir. Bu tür karşılaştırmalı çalışmaların belirli bir periyotla yapılması, bu alanda çalışma yapacak araştırmacılara alandaki gelişmeler hakkında somut bir bakış açısı kazandırabilmesi açısından önemlilik arz etmektedir.

\section{Kaynaklar}

Ahi, B., \& Kıldan, A. O. (2013). Türkiye'de okul öncesi eğitimi alanında yapılan lisansüstü tezlerin incelenmesi (2002-2011). Mehmet Akif Ersoy Üniversitesi Eğitim Fakültesi Dergisi, 27, 23-46.

Altun, D., Şendil, Ç. Ö., \& Şahin, I. T. (2011). Investigating the national dissertation and thesis databate in the field of early childhood education in Turkey. Procedia Social and Behavioral Sciences, 12, 483-492.

Bahçacl, Ö., \& Türkoğlu, B. (2019). Türkiye'de okul öncesi öğretmenleri ve okul öncesi öğretmen adayları ile ilgili yapılan lisansüstü tezlerin incelenmesi. Turkish Studies Educational Sciences, 14(4), 1103-1139.

Bayraktar, V., \& Temel, F. (2014). Okuma yazmaya hazırlık eğitim programının çocukların okuma yazma becerilerine etkisi. Hacettepe Üniversitesi Eğitim Fakültesi Dergisi, 29(3), 8-22.

Beaty, J. J. (2018). Erken Çocuklukta 50 Okuryazarlık Stratejisi (Çev. Alisinanoğlu, F. ve Kaya, S. D.). Ankara: Pegem.

Bilgin, N. (2006). Sosyal bilimlerde içerik analizi. Teknikler ve örnek çalışmalar. Ankara: Siyasal Kitabevi. 
Bredekamp, S. (2015). Erken Çocukluk Eğitiminde Etkili Uygulamalar. (Effective Practices in Early Childhood Education, 2nd Edition). (Çev. Hatice Zeynep İnan ve Taşkın İnan). 343-345. Ankara: Nobel Yayıncılık.

Can Yaşar, M., \& Aral, N. (2011). Türkiye'de okul öncesinde darama alanında yapılan lisansüstü tezlerin incelenmesi. Mehmet Akif Ersoy Üniversitesi Eğitim Fakültesi Dergisi, 22, 70-90.

Creswell, J. W. (2013). Araştırma deseni (Çev Edt Demir, S. B.). Ankara: Eğiten Kitap.

Demirtaş ilhan, S., \& Tantekin Erden, F. (2019). A Content analysis of graduate theses concerning early childhood education in Turkey. Turkish Journal of Education, 8(2), 86-108.

Dickinson, D. K., \& Neuman, S. B. (2018). Handbook of Early Literacy Research (G.Akoğlu \& C. Ergül, Çev.). Ankara: Nobel.

Dündar, H., \& Hareket, E. (2017). Türkiye'de çocuk hakları bağlamında yapılan lisansüstü tezlerin araştırma eğilimlerinin incelenmesi. Manas Sosyal Araştırmalar Dergisi, 6(1), 77-94.

Elliott, E., \& Olliff, C. (2008). Developmentally appropriate emergent literacy activities for young children: Adapting the Early Literacy and Learning Model (ELLM). Early Childhood Education Journal, 35, 551- 556.

Enerem, D. (2018). 60-72 ay arası çocuklarda erken okuryazarlık becerilerinin çeşitli değişkenler açısından incelenmesi (Yayımlanmamış yüksek lisans tezi). Maltepe Üniversitesi Sosyal Bilimler Enstitüsü, i̇stanbul.

Erdoğan, Ö. (2012). Illköğretim birinci sınıf öğrencilerinin fonolojik farkındalık becerileri ile okuma becerileri arasındaki ilişki. Eğitim ve Bilim, 37(166), 41-51.

Ergül, C., Dolunay Sarıca, A., Akoğlu, G., \& Karaman, G. (2017). The home literacy environments of Turkish kindergarteners: Does SES make a difference? International Journal of Instruction, 10 (1), 1308-1470.

Evans, M. A., Bell, M., Shaw, D., Moretti, S., \& Page, J. (2006). Letter names, letter sounds and phonological awareness: an examination of kindergarten children across letters and of letters across children. Reading and Writing, 19(9), 959-989.

Ferah, A. (2001). Her Yönüyle Türkçe Illk Okuma-Yazma. İstanbul: MEB Yayınevi.

Gök, N. F. (2013) Anaokullarında erken okuryazarlık çevresinin değerlendirilmesi ve sınıf ortamının çocukların erken okuryazarlık davranışlarına etkisi (Yayımlanmamış doktora tezi). Gazi Üniversitesi Eğitim Bilimleri Enstitüsü, Ankara.

Gökçe, O. (2006). İ̧erik analizi: Kuramsal ve pratik bilgiler. Ankara: Siyasal Kitabevi.

Gül, G. (2007). Okuryazarlık sürecinde aile katılımının rolü. Ankara Üniversitesi Eğitim Bilimleri Fakültesi Özel Eğitim Dergisi, 8 (1), 17-30.

Gürel, Y. (2018). Konuşma bozukluğu olan/kardeşlerinde özgül öğrenme bozukluğu öyküsü olan okul öncesi çocukların sağlıklı kontrollerle erken okur-yazarlık test puanları açısından karşılaştırılması (Yayımlanmamış tıpta uzmanlık tezi). Ankara Üniversitesi Tıp Fakültesi Çocuk ve Ergen Ruh Sağlığı ve Hastalıkları Anabilim Dalı, Ankara.

Gürsoy, F., Aydoğdu, F., Aysu, B., \& Aral, N. (2019). Engelli çocuklarda oyun ile ilgili yapılan lisansüstü tezlerdeki eğilimler. Çocuk ve Gelişim Dergisi (ÇG-D), 2(4), 44-57.

Haney, M., \& Hill, J. (2004). Relationships between parent-teaching activities and emergent literacy in preschool children. Early Child Development and Care, 174(3), 215-228.

Işıkoğlu Erdoğan, N. (2016). Erken çocukluk döneminde çocuk-ebeveyn birlikte okuma etkinliklerinin incelenmesi. Kastamonu Eğitim Dergisi, 24(3), 1071-1086.

Justice, L. M., \& Ezell, H.K. (2001). Word and print awareness in 4-year-old children. Child Language Teaching and Therapy, 17(3), 207-225.

Kalburan, F. N. (2010). Öykülerle alfabe. Ankara: Eğiten Kitap.

Karadağ, R. (2014). Okuma ilgisi, tutumları ve alışkanlığı konusunda yapılmış çalışmaların lisansüstü tezlere dayalı analizi: YÖK ve ProQuest veri tabanları örneklemi. Pamukkale Üniversitesi Eğitim Fakültesi Dergisi, 35(1), 1-17.

Karaman, G. (2015). Erken okuryazarlık becerilerinin tarihsel gelişimi, kuramsal temelleri ve kapsamı. Z.F. Temel (Ed.), Dil ve Erken Okuryazarlık, Sekizinci Baskı, Ankara: Hedef. 
Karoğlu, H., \& Esen Çoban, A. (2019). Türkiye'de okul öncesi eğitimde dil gelişimi ile ilgili yapılan lisansüstü tezlerin incelenmesi. Erzincan Üniversitesi Eğitim Fakültesi Dergisi, 21(1), 211-229.

Kargın, T., Güldenoğlu, B., \& Ergül, C. (2017). Anasınıfı çocuklarının erken okuryazarlık beceri profili: Ankara örneklemi. Ankara Üniversitesi Eğitim Bilimleri Fakültesi Özel Eğitim Dergisi, 18(1), 6187.

Kargın, T., Ergül, C., Büyüköztürk, Ş., \& Güldenoğlu, B. (2015). Anasınıfı çocuklarına yönelik Erken Okuryazarlık Testi (EROT) geliştirme çalışması. Ankara Üniversitesi Eğitim Bilimleri Fakültesi Özel Eğitim Dergisi, 16(3), 237-268.

Kaytez, N., \& Durualp, E. (2014). Türkiye'de okul öncesinde oyun ile ilgili yapılan lisansüstü tezlerin incelenmesi. Uluslararası Türk Eğitim Bilimleri Dergisi, 2(2), 110-122.

Kınık, B., Okyay, Ö., \& Aydoğan, Y. (2016). 24-36 aylık çocuklarda aile katılımlı çevre eğitiminin dil gelişimine etkisinin incelenmesi. Kastamonu Eğitim Dergisi, 24(5), 2143-2156.

Lerner, J. (2000). Learning disabilities: Theories, diagnosis, and teaching strategies. BostonNew York: Houghton MifflinCompan.

MacLean, J. (2008). Library preschool storytimes: Developing early literacy skills in children. https://ed.psu.edu/goodling-institute/professional-development/judy-maclean-librarypreschool-storytimes'tan alınmıştır. Erişim Tarihi:10.08.2020.

McGee L.M., \& Morrow L.M. (2005). Teaching Literacy in Kindergarten. New York: The Guilford Press.

Mutlu, E. (2018). An investigation of Turkish Mothers' narrative styles and their relation to children's narrative comprehension (Yayımlanmamış yüksek lisans tezi). İhsan Doğramacı Bilkent Üniversitesi Ekonomi ve Sosyal Bilimler Enstitüsü, Ankara.

National Early Literacy Panel. (2008). Developing early literacy: Report of the national early literacy panel. Washington, DC: National Institute for Literacy.

Oğuz Haçat, S., \& Demir, F. B. (2019). Eğitim alanında okuryazarlık üzerine yapılan lisansüstü tezlerin analizi. The Journal of Anatolian Cultural Research, 3(2), 116-145.

Özen Uyar, R., \& Ormancı, Ü. (2016). Türkiye'de okul öncesi dönem fen eğitimi araştırmalarında güncel eğilimler: bir tematik analiz çalışması. Ö. Demirel ve S. Dinçer, (Eds.), Eğitim Bilimlerinde Yenilikler ve Nitelik Arayışı içinde (559-584). Ankara: Pegem Akademi.

Phillips, B. M., \& Lonigan, C. J. (2009). Variations in the home literacy environment of preschool children: a cluster analytic approach. Scientific Studies of Reading, 13(2), 146-174.

Saatçi, F. Z. (2019). 60-72 aylık işitme kayıplı ve işitme kayıplı olmayan çocuklarda erken okuryazarlık becerilerinin karşılaştırılması (Yayımlanmamış yüksek lisans tezi). KTO Karatay Üniversitesi Sağlık Bilimleri Enstitüsü, Konya.

Şad, S. N., \& Sarı, M. (2019). İngilizce öğretmenlerinin erken yaşta yabancı dil öğretimine ilişkin yeterlilik düzeyleri (Kütahya ili örneği). Inönü Üniversitesi Eğitim Bilimleri Enstitüsü Dergisi, 6(12), 144163.

Sarı, B., \& Altun, D. (2018). Okul öncesi dönem çocuklarının hikâye anlama ile zihin kuramı becerileri arasındaki ilişkinin incelenmesi. Ana Dili Eğitimi Dergisi, 6(4), 945-960.

Scarborough, H. S. (2018). Erken Dil ve Okuryazarlık Becerilerinin Sonraki Okuma Güçlükleri ile ilişkisi. (C. Ergül, Çev.) G. Akoğlu ve C. Ergül (Editörler), Erken Okuryazarlık Araştırmaları El Kitabı (ss. 97-110). Ankara: Nobel Yayıncılık.

Sezgin, D. (2019). Koklear implantlı okul öncesi çocuklarda erken okur yazarlık becerilerinin araştırılması (Yayımlanmamış yüksek lisans tezi). Ege Üniversitesi Sağlık Bilimleri Enstitüsü, İzmir.

Spira, E. G., Bracken, S. S., \& Fischel, E. J. (2005). Predicting improvement after first-grade reading difficulties: The effects of oral language, emergent literacy, and behaviour skills. Developmental Psychology, 41(1), 225-234.

Tercanlı Metin, G., \& Gökçay, G. (2014). Bebeklik ve erken çocukluk döneminde kitap okuma: Çocuk sağlığı izlemlerinde etkili bir gelişim önerisi. Çocuk Dergisi 14(3), 89-94.

Whitehurst, G.J., \& Lonigan, C.J. (2001). Emergent literacy: Development from pre-readers to readers. In S. Neuman and D. Dickinson (Eds.). Handbook of early literacy development (pp. 11-29). New York: Guilford. 
Yarar, S., \& İnan, H. Z. (2015). Kurum/ev erken dil ve okuryazarlık gözlem aracının geçerlik ve güvenilirlik çalışması. Electronic Turkish Studies, 10(15), 821-840.

Yazıcı, E., \& Kandır, A. (2018). Erken okuryazarlık becerilerinin ev ortamında desteklenmesine ilişkin çalışmaların incelenmesi. Gazi University Journal of Gazi Educational Faculty (GUJGEF), 38(1), 101-135.

Yıldııı, A., \& Şimşek, H. (2018). Sosyal Bilimlerde Nitel Araştırma Yöntemleri (11. Baskı). Ankara: Seçkin Yayınevi.

Zucker, T. A., Cabell, S. Q., Justice, L. M., Pentimonti, J. M., \& Kaderavek, J. N. (2013).The role of frequent, interactive prekindergarten shared reading in the longitudinal development of language and literacy skills. Developmental Psychology, 49(8),1425-1439.

\section{Extended Abstract}

\section{Introduction}

Early childhood has a very important place in human life. This period is considered as the magic years when rapid advances are recorded in all developmental areas in children and is of the utmost importance in acquiring socio-emotional, cognitive, and language skills. Considering that its development is holistic, a complex and active process is followed in early childhood, which affects and determines the acquisition of literacy skills. The early literacy skill is described as knowledge, skills and attitude that children should have prior to literacy training in primary school in the literature (Evans, Bell, Shaw, Moretti \& Page, 2006; Gök 2013; Lerner 2000; Scarborough, 2018; Whitehurst \& Lonigan, 2001) and is considered one of the most important indicators of reading success. In addition, these studies have considered literacy as a developmental process and drew attention on the first years in life.

Many studies conducted recently have shown that early literacy skills are one of the basic requirements that support a child's lifelong learning as well as strongly supporting their future literacy and academic skills (Beaty, 2018; Dickinson \& Neuman, 2018; Kalburan, 2010). However, previous studies have revealed that when they receive formal literacy training, children who could not interact enough with the environment in early childhood and who could not have sufficient early literacy skills may face certain difficulties related to visual perception (Ferah 2001), vocabulary (Karaman, 2015), phonological awareness (Erdoğan, 2012), writing skills (Bayraktar \& Temel, 2014), recognizing letters and words (Whitehurst \& Lonigan, 2001), and reading skills (McGee \& Morrow, 2005; National Early Literacy Panel [NELP], 2008).

Studies conducted in recent years in the relevant literature have demonstrated that the number of postgraduate theses conducted on early literacy skills are increasing every day. Graduate theses support the research aspect of universities and have an important function in revealing developments in the field. The present study aimed to identify research trends of postgraduate theses conducted on early literacy in the last five years in Turkey and abroad. Based on the idea that analyzing studies conducted on a certain field by then would guide future studies, the distribution of postgraduate theses on early literacy between 2015-2020 was analyzed by the year of publication, university, target group, method, and data collection tools. One of the most important purposes in the present study is to conduct an assessment and present studies on early literacy to researchers who want to study on this field, preschool teachers, and families, as well as shedding light on future studies.

\section{Method}

In order to select theses on this field, scanning was conducted between 29.03 .2020 and 27.04.2020 on databases such as Theses Global, ProQuest Dissertations and the Council of Higher Education's National Thesis Center. Keywords such as "early literacy, emergent literacy, preschool literacy" were used in the scanning process and 80 postgraduate theses in total were found. In addition, an advanced scanning was conducted using the same keywords on CoHE's National Thesis Center database and the same postgraduate theses were found. In terms of subject areas of postgraduate theses on Theses Global and ProQuest Dissertations databases using these keywords, it was seen that there was a postgraduate thesis on psychology $(n=1)$ whereas there were postgraduate 
theses on ear-nose-throat ( $n=2)$, psychology $(n=2)$, and psychiatry $(n=1)$ on CoHE's National Thesis Center database. In addition, even though one of the master's theses was on education and training, it was excluded from the sample given that it focused on foreign language literacy. The criterion in the present study is that theses are on early literacy, they are included in the field of education and training, and that they are registered and accessible through ProQuest Dissertations and Theses and CoHE's National Thesis Center. 73 postgraduate theses, in Turkey and abroad, in total meeting these criteria were included in the study. The study is a qualitative one and data were collected by the document analysis technique. These theses included in the study were collected by scanning the relevant literature and through "Thesis Analysis Form" developed by researchers analyzing the data collection tools used in similar studies on different areas. This form included information on the year of publication, thesis type, field, title, study field, research type, sample, data collection technique, and data collection tool while frequency $(f)$ was employed in data analysis.

\section{Result and Discussion}

Based on research findings in the present study in which postgraduate theses on early literacy conducted in Turkey and abroad were investigated, it is remarkable that the number of doctoral thesis in the field in Turkey is very low and it is recommended that the field be studied in a more detailed manner at doctoral level. In addition, the present study has revealed the need for studies on early literacy in which managers and academics are included in Turkey and the need for planning future studies on the field. Based on research findings, choosing a mixed method in which both quantitative and qualitative methods are used in order to provide more in-depth information on early literacy and using research designs such as longitudinal studies and action research will contribute more to the field, children, and therefore, to the future. This study is limited to postgraduate theses conducted in our country and abroad between 2015-2020. More detailed information can be obtained by expanding the scope of the study. Conducting such comparative studies in a certain period is important in terms of providing researchers who will conduct studies in this field a concrete perspective on the developments in the field. 